
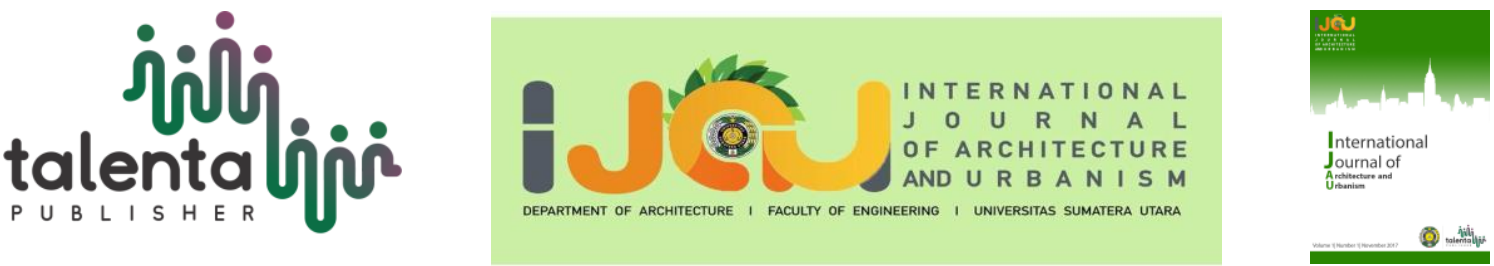

\title{
Revitalization of Koek \& Co Building as the Center for Automotive Modification; Hi-Tech Architecture Approach
}

\author{
Rudolf Sitorus $^{1}$, Novi Anggriana Harahap ${ }^{1^{*}}$ \\ ${ }^{1}$ Architecture Department, Faculty of Engineering, Universitas Sumatera Utara, Medan, Indonesia
}

\begin{abstract}
The growth in the number of car users continues to increase to reach 537,054 units. This increase affects the need for a place for car maintenance and modification. Unfortunately, the City of Medan does not yet have a centralized, adequate, and complete car modification place. These factors are the reason for designing the Automotive Modification Center in Medan, a place or facility that provides all kinds of modifications and standard services expected to make it easier for people to channel their hobbies without being hindered by existing facilities. The application of Hi-tech architecture in this design is applied to the circulation system and building facade. With the revitalization of the Koek \& Co building to become an automotive modification center, it is hoped to educate the public about the Koek \& Co building's history. The Koek \& Co building was the largest workshop building in the city of Medan in 1937 and witnessed the development of the automotive world in Indonesia, especially Medan.
\end{abstract}

Keyword: car modification, hi-tech architecture

Received 29 September 2021 | Revised 31 October 2021 | Accepted 31 October 2021

\section{Introduction}

Technological developments from time to time are increasingly advanced, one of which is in the automotive sector. This is due to the high growth in the current number of transportation which causes technology competition and car modifications to occur. As a result, car modifications are very popular, from young to old. They develop their car products through information from magazines, television, and digital media.

From the data (Figure 1) [1], below we can see how the number of car use in North Sumatra from 2007-2017 continues to increase to reach 537,054 units so that this number is also directly proportional to the need for car modification and maintenance. The development of car

\footnotetext{
*Corresponding author at: Architecture Department, Faculty of Engineering, Universitas Sumatera Utara, Perputakaan street, J07 Building, Medan, 20155, Indonesia

E-mail address: novi.anggriana@gmail.com
} 
modification in Indonesia is increasing not only in terms of quantity but also in terms of quality. Car modifications can represent the character of the owner of the car. Aside from being a symbol, car modification is also used as a hobby and interacting with fellow modification enthusiasts.

\begin{tabular}{|cccccc|}
\hline Tahun & Mobil Penumpang & Mobil Bus & Mobil Barang & Sepeda Motor & Jumlah \\
\hline 2007 & 257729 & 29228 & 180384 & 2429571 & 2896912 \\
2008 & 279996 & 29507 & 189857 & 2805368 & 3304728 \\
2009 & 297922 & 29498 & 194946 & 3091510 & 3613876 \\
2010 & 327467 & 29978 & 203452 & 3478230 & 4039127 \\
$2011^{\circ}$ & 356931 & 71112 & 217254 & 3924007 & 4569304 \\
$2012^{\circ}$ & 386144 & 71590 & 231750 & 4292933 & 4982417 \\
2013 & 416405 & 71900 & 242445 & 4584431 & 5315181 \\
2014 & 441191 & 71087 & 249919 & 4795755 & 5558952 \\
2015 & 470280 & 72317 & 258060 & 5022752 & 5824720 \\
2016 & 496002 & 74739 & 309585 & 5917939 & 6798265 \\
2017 & 537054 & 74984 & 319003 & 6162974 & 7094015 \\
\hline
\end{tabular}

Figure 1 Number of Car Users from Year to Year

In Medan itself, the development of automotive enthusiasts has also increased from the preindependence era to the present. For example, around 1937, Koek \& Co (General Motors) was the largest car repair shop in Medan, namely the Chevrolet. However, in early 1945, when Indonesian independence was established, Koek \& Co a workshop under POLITAKS. So that through this historical evidence can be seen the development of automotive from the past until now.

Medan currently does not have a complete and adequate modification place service; therefore, it is necessary to establish a car modification center that is complete and easily accessible to all levels of the general public, community, and students.

The choice of this theme considers the relationship between the advancement of car technology, which continues to increase, and the development of building technology, such as the use of material technology, types of structures, and others. So it is hoped that this building can become one of the places where modifications are always updated with the latest technology so that the result of this design has a sophisticated character, structural exploration, and sporty. 


\section{Literature Review}

\subsection{Definition Of Revitalization}

According to R.M. Sinaga [2], revitalization is an effort to recycle (recycle) to give new vitality and increase the existing vitality or revive the vitality that already existed at first but has faded/decreased caused by several factors. Revitalization efforts can occur either at the microscale of the City, such as roads or buildings.

In carrying out the process of reviving a cultural heritage, it can include new functions without leaving the spirit of the place (Spirit of Place). In particular, revitalization includes the restoration of buildings and protected environments and cultural heritage areas adjusted to the established classification. Revitalization in cultural heritage areas must be planned following the applicable City/Regency Rencana Tata Ruang Wilayah (RTRW).

\subsection{Definition of Automotive Modification}

According to A. Febrianda [3], automotive is related to tools that can rotate and move on their own. In addition, automotive is related to motors or machines that can move objects larger than the engine/motor drive. However, unfortunately, most people equate the term automotive with transformation tools such as cars, motorcycles, and buses. Of course, this is wrong because automotive refers to the engine or motor as the driving force of a car or other type of transportation.

According to Kamus Besar Bahasa Indonesia [4], modification is a change, replacement, or addition of something. Modification changes from its original condition, so automotive modification is a change made to a vehicle that makes its condition different from before.

\subsection{Classification of Car Repair Shop}

According to Undang-Undang Nomor 11 Tahun 2020 Tentang Cipta Kerja Sektor Transportasi [5], motor vehicle public workshops function to repair and maintain motorized vehicles to remain roadworthy. So that it can be interpreted that a workshop is a place for maintenance and repair of motorized vehicles so that they are suitable for use.

According to A.S. Hasibuan [6], four types of workshops are distinguished based on their service facilities. The first is a dealer workshop, which is part of a dealer that provides aftersales service and only serves one particular brand. Services in the form of routine maintenance to repair spare parts. Second, public service workshops are independent workshops that serve not only one brand of car but also several brands. Therefore, this workshop is not an after-sales service from a particular dealer brand. Third, special service workshops, namely workshops that have specializations such as body repair workshops, radiator, air conditioning, or balancing workshops, these specialization workshops have special equipment needs by the services offered. Fourth, the four mobile unit workshops are workshops that provide repairs carried out 
at the location of the consumer's car. This type of workshop consists of several tow vans, which are patrolled periodically. Again, this type of workshop is under the auspices of certain brand dealers.

\subsection{Koek \& Co (Poltaks)}

Around 1937, Koek \& Co (General Motors) was the largest car assembly or repair shop in Medan. However, in early 1945 when Indonesia became independent, this building was taken and used as a workshop which was named Poltaks. The name Poltaks is a name taken from the child who owns this building, namely Edison Poltaks Silitonga. Then in 1977 - until now bought by Jansen Chanjaya as private property. This building is used as a place for travel and goods expedition, namely IndaTaxi. Until now, this building has been managed by the second generation.

\subsection{Definition of Hi-tech Architecture}

According to Kamus Besar Bahasa Indonesia [4], Hi-tech is high technology. This theme relates to technological advances growing from time to time; in line with the world of buildings, various variations and various uses of modern material technology and always support the times.

In architecture, the term High-tech describes the technology used in buildings. High tech architecture is known thanks to architects Renzo Piano and Ricard Rodger with the Georges Pompidou Center, Paris, which uses glass, metal, and exposed materials in the building's utility network, which is used as an ornament.

According to G.S. Watung [7], the notion of architecture is an architectural flow that leads to architectural ideas that highlight the impression of structure and technology in a building. The characteristics of high-tech architecture are buildings that use glass, metal, and plastic materials.

\subsection{Principles of Hi-Tech Architecture}

According to M. Telew [8], six important things characterize high-tech architecture, namely: first, inside-out, namely in building service areas, structures and utilities are always highlighted on the exterior so that they can form ornaments. Second, the celebration of process, namely hitech, emphasizes building construction so that ordinary people and scientists easily understand it. Third, transparency, layering, and movement, namely high-tech buildings, always use these three elements to the fullest. Fourth, flat bright clouring, which uses bright colors in the building to distinguish the structure and utility of the building. Fifth, a lightweight filigree of tensile member, namely the use of thin cross-sectional steels as a Doric column. Sixth, optimistic Confidence in Scientific Culture, which is optimistic about the latest science and technology. 


\section{Research Methode}

The design method is the process of designing a building, which consists of data collection, analysis, concept synthesis, and drawing. According to M.N. Hasan [9], in the process of designing data and facts are things that can be the basis of the design idea. According to D.C. Prananda [10], the data is divided into two, namely primary data and secondary data based on the source. Primary data is data obtained and collected by researchers directly from field locations such as the existing environment, location, climatic conditions, utilities, others. Meanwhile, secondary data is data collected from various pre-existing sources through literature studies and comparative studies of similar projects. Then the data obtained is connected with the theories of the approach that will be applied. Then the results of the data obtained will be used as a guide in designing the Revitalization of the Koek \& Co Building as an Automotive Modification Center.

\section{Result And Analysis}

The revitalization of the Koek \& Co building is intended as an automotive modification center that can accommodate the needs of the Medan city community regarding automotive. The activities of this building include standard service, modification service, and trading of car spare parts. The design of this building applies a Hi-Tech architectural approach. According to F.S. Fairuzy [11], Hi-Tech architecture is an architectural approach that interprets technological systems applied to a building, such as glass and metal materials exposed to form an ornament.

\subsection{Design Location}

The location of the site is on Jl. Brigadier General Katamso, AUR village, Medan Maimun District, Medan City, North Sumatra. Based on calculations via google maps, the project site has an area of 13,000 $\mathrm{m}^{2}$ (Figure 2).

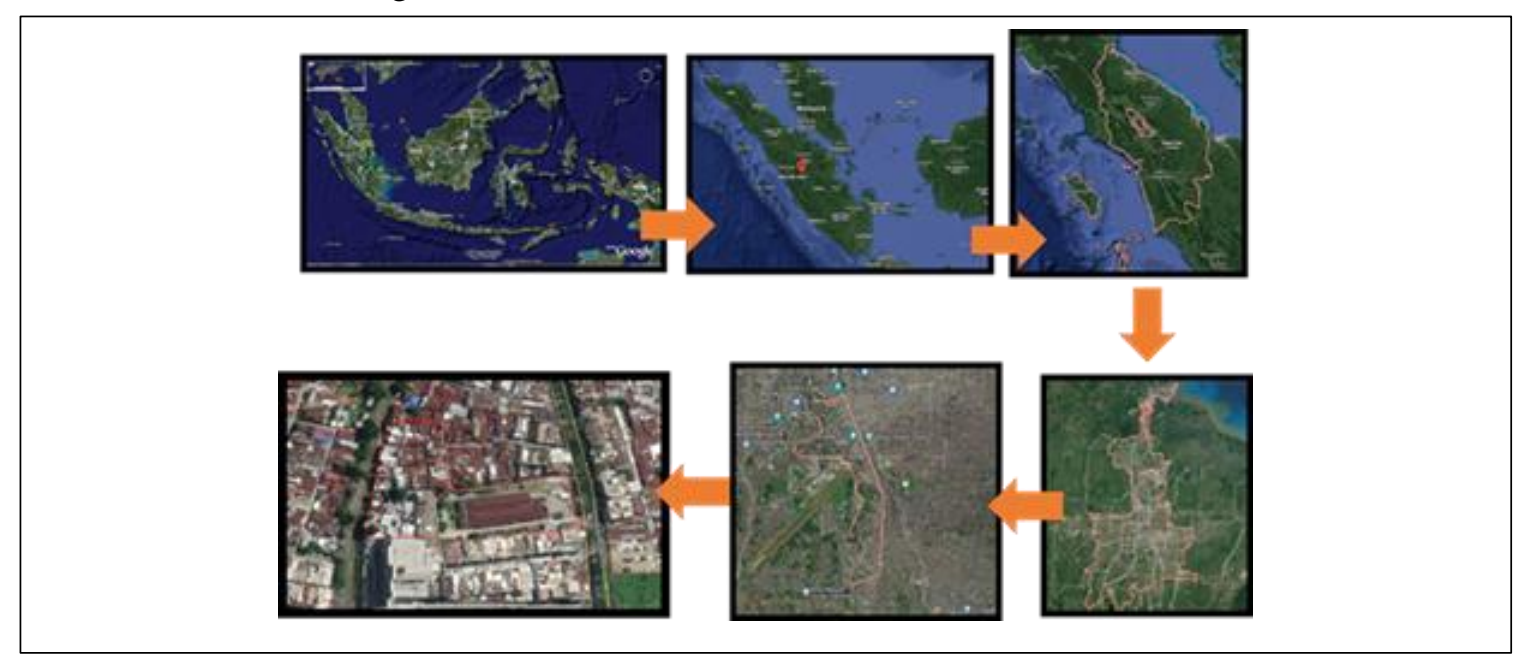

Figure 2 Project Location 


\subsection{Building Mass Concept}

The mass of the building is created from the shape of the tread in the form of an L, which is then given additional forms of circles and curves. Helps to represent the shape of the river and also supports the theme of the building (Figure 3).

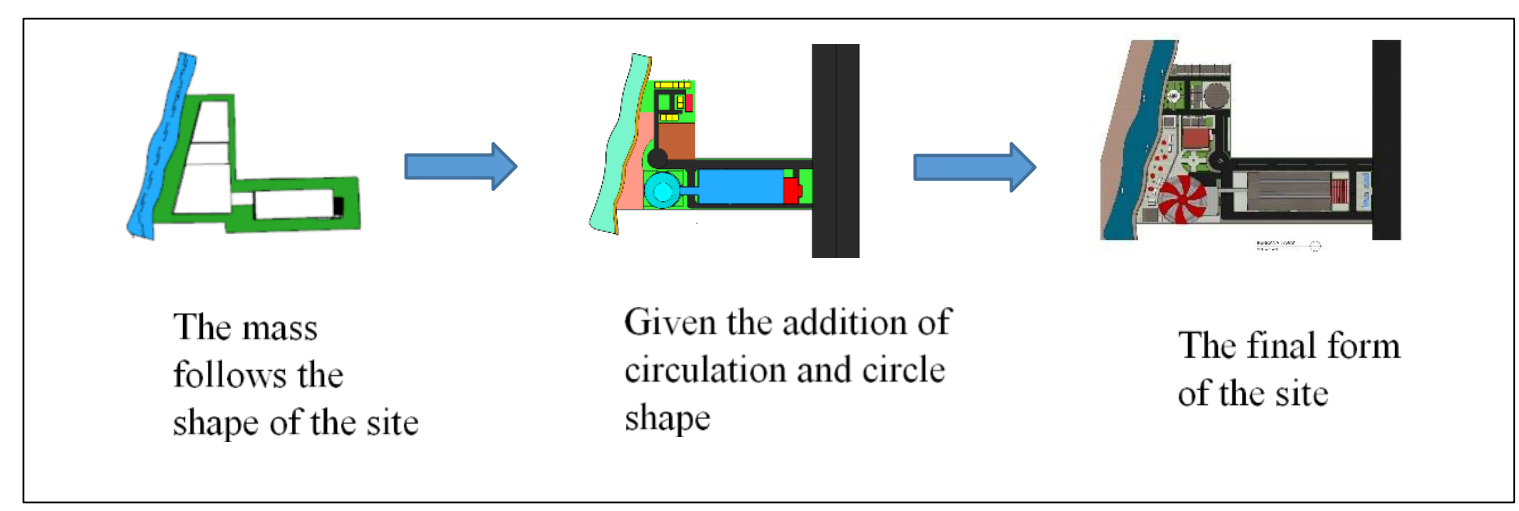

Figure 3 Building Mass Concept

\subsection{Circulation and Parking Concept}

According to I.G.A.E. Suwintari [12], the planning of space outside the circulation and parking lanes is the most important part that forms the framework/network of spatial relationships (spatial datum). In this system, the circulation path accommodates the circulation of motorized vehicles and pedestrians. Thus the circulation system can be a place for social interaction for all space users to become a means of social interaction.

Several types of circulation are distinguished at this site, namely pedestrian circulation, twowheeled vehicle circulation, and four-wheeled circulation. In addition, there is the eastern part of the site or from the Bridgend Katamso road for circulation in and out of the site (Figure 4).

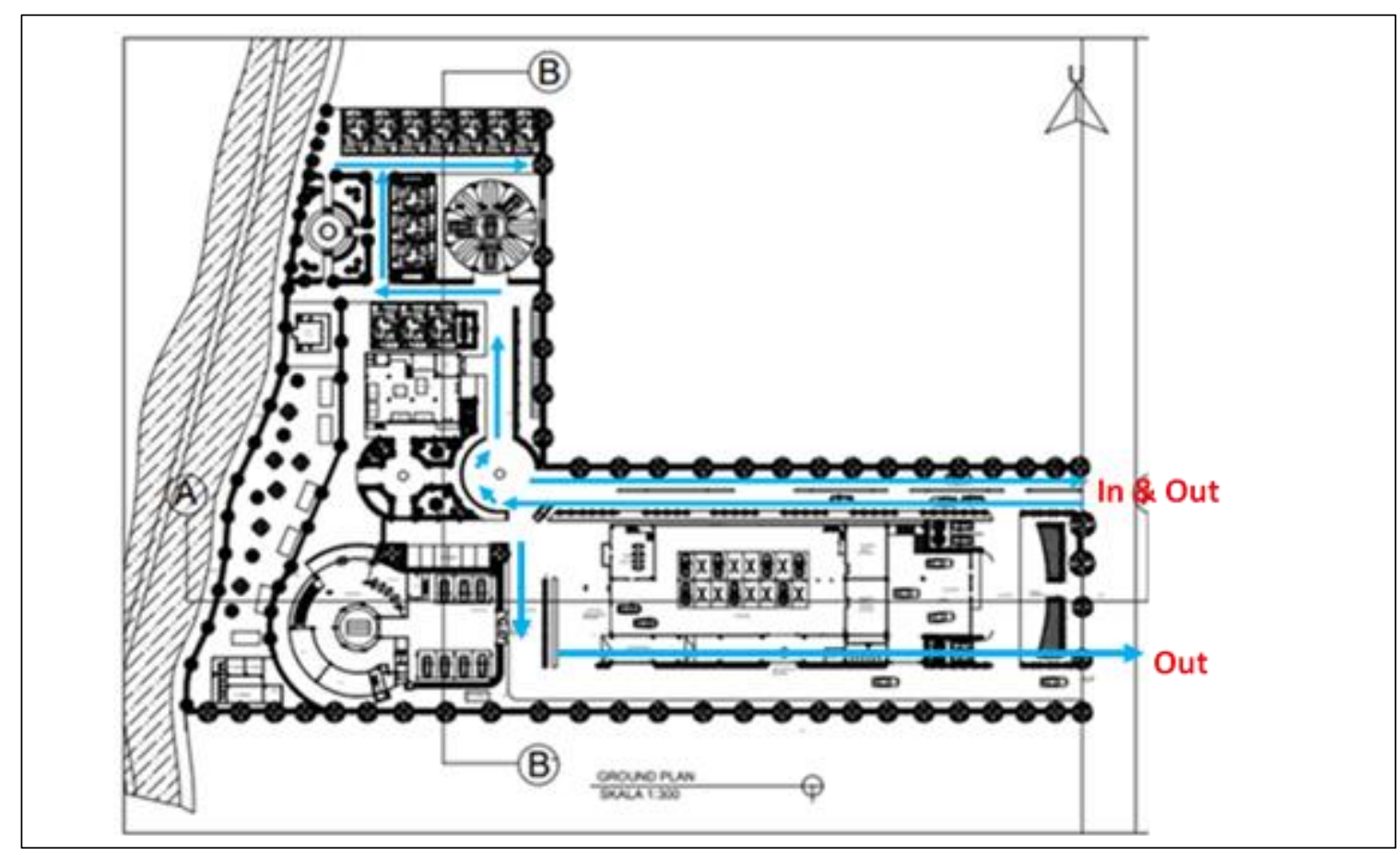

Figure 4 Circulation Concept 
According to I.G.R. Purbanto [13], roadside parking on the side of the road greatly disrupts the performance of roads, which can create congestion, this is caused by the high price of land so that there is not enough parking space So we need a parking lot model that does not require a large area but can accommodate a large enough volume of vehicles, one of which is by applying the concept of a vertical parking building. Make it easier for the operational system to apply the APS (Automatic Parking System) system to the parking building. According to A.A.Sani [14]. The APS system is designed to be able to move the vehicle automatically with the help of a motor-powered engine that can move from left to right or right to left and vertically or horizontally. The advantage of the vertical parking building system is that it can save space usage, so it does not require a very large area (Figure 5).

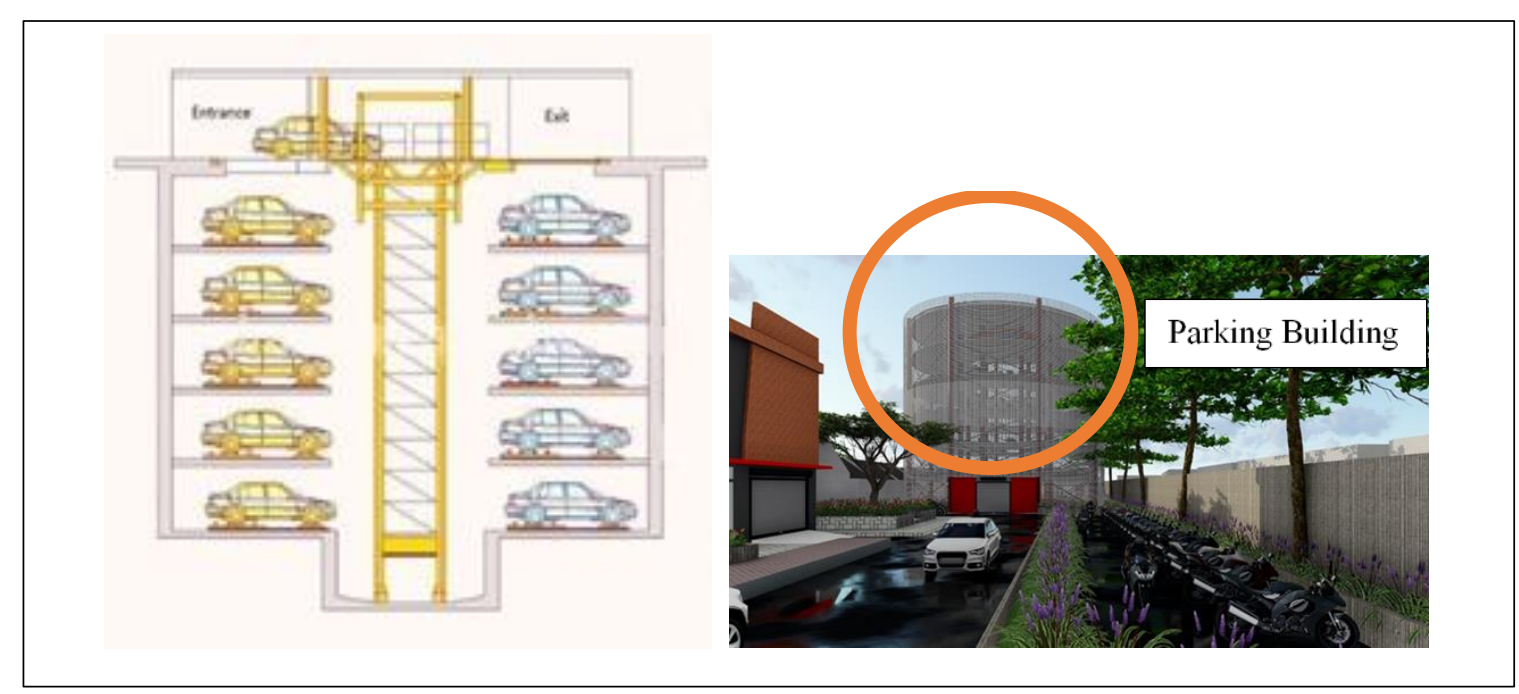

Figure 5 Parking Building Concept

\subsection{Façade Concept}

According to K. Akbar [15], the facade is the outermost part of the building that functions not only as an identity but also as a direct intermediary between the outside and inside conditions. The function of the facade can be better if it can protect the building from the outside weather. By moving and making the facade more dynamic, it can make the facade more adaptable to outside conditions and can accommodate the needs in the building, such as light and air. The theme applied to the design of the Center for Automotive Modification in the City is high-tech architecture. High-tech architecture has characteristics such as transparency, using layering, movement, and technology. The application of technology to this facade is a kinetic facade.

According to G.D.R. Widasari [16], a kinetic facade is a facade that can move automatically and is responsive to the surrounding environmental conditions. Kinetic facades are defined in the repair and modification workshop area (Figure 6). 

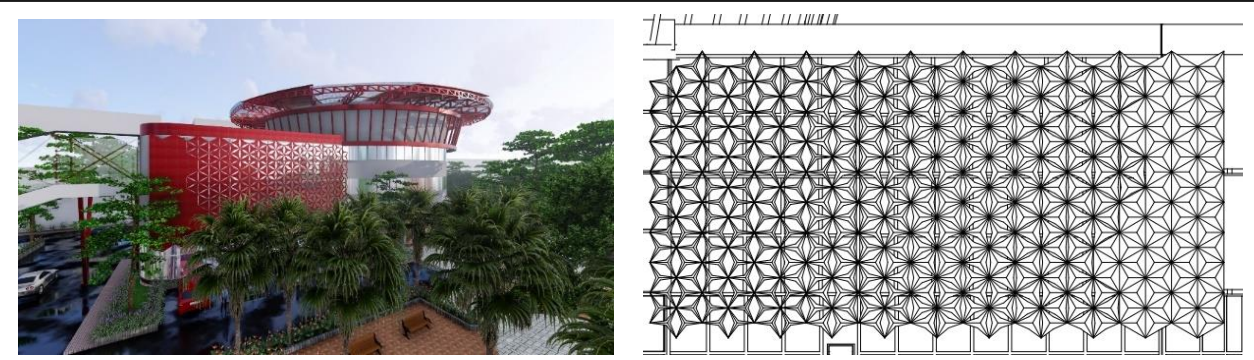

Figure 6 Concept Facad In The Repair And Modification Workshop Area

In the parking building, aluminum is used, which is cut to a size of $10 \mathrm{x} 10$, which is then arranged on the parking facade so that when the wind blows, the aluminum plates will move and create the illusion of the facade moving (Figure 7).

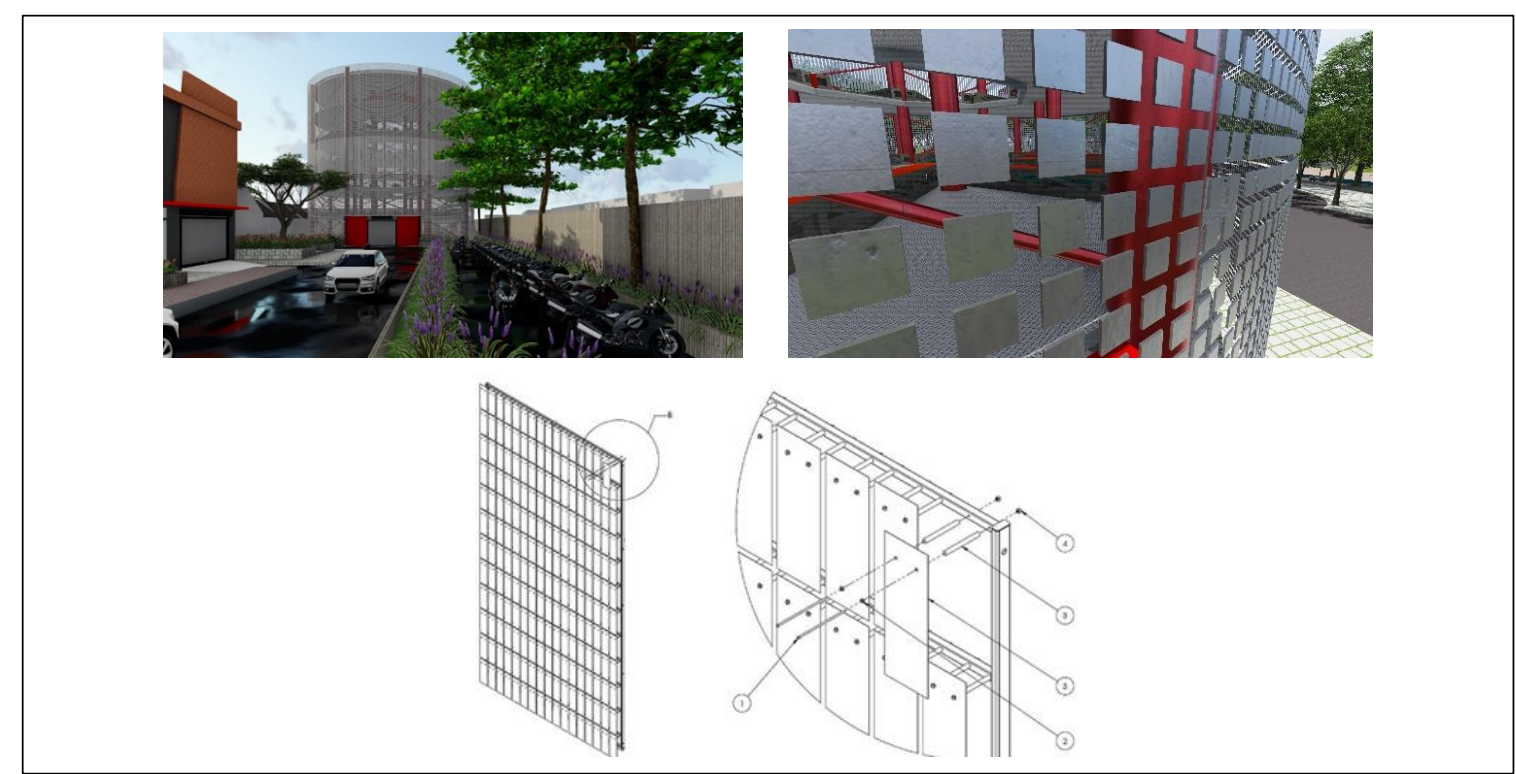

Figure 7 Concept Façade In The Parking Building

\subsection{Workshop waste treatment}

According to the Environment Agency [17], motor vehicle repair shops function as a place to change vehicle oil and also carry out vehicle washing so that it is a place to produce wastewater containing oil and detergent. Used oil that is not managed properly can cause work accidents due to slippery floor conditions and can also cause environmental pollution if wastewater is directly discharged into city drains. So it requires special handling of workshop waste. At this Automotive Modification Center, there are several stages of screening to produce waste that is safe for the environment.

\section{Conclusion}

Revitalization of Koek \& Co Building as an Automotive Center located on Jl. Brijgend Katamso, Aur Village, Medan Maimun District, Medan City. The purpose of this design is to provide a centralized and complete, and adequate modification facility. In addition, the Revitalization of the Keok \& Co Building as an Automotive Center can provide education to the public that Medan City has a historic building in the automotive sector, namely the Koek \& Co 
building, which is the largest workshop in Tanah Deli. Furthermore, the location of the Koek \& Co building, which is adjacent to the Deli River, also provides education to the public that the river is not only the back of the building that does not need attention, but the river is one element that has potential for tourism and beauty for a city.

\section{Acknowledgment}

This research is a study of the Automotive Modification Center Design, which is expected to be a centralized and complete solution provider for modification facilities and can become one of the historical icons of Medan City. This research can be a recommendation for the city government as a solution for historic places.

\section{REFERENCES}

[1] Badan Pusat Statistik Provinsi Sumatera Utara. Jumlah Kendaraan Bermotor yang Terdaftar untuk 2004-1014. [Online]. https://sumut.bps.go.id/statictable/2015/03/31/69/jumlah-kendaraan-bermotor-yangterdaftar-unit-2004---2013.html

[2] Risma Margaretha Sinaga, "Revitalisasi tradisi: Strategi mengubah stgma Kajian piil pesenggiri dalam budaya lampung. Masyarakat Indonesia (jurnal ilmu-ilmu sosial Indonesia)," Jurnal Masyarakat Indonesia, vol. 40, No.1, pp. 109-126, 2014.

[3] Aryawa Febrianda, Krisnawati Eny, and Rully, "Surakarta Otomotif Center Berpendekatan Arsitektur High-Tech," Jurnal Teknik Sipil dan Arsitektur, no. 2, 2019.

[4] Kemendikbud, Kamus Besar Bahasa Indonesia, Badan Pengembangan dan Pembinaan Bahasa, Kementerian Pendidikan dan Kebudayaan Republik Indonesia., 2016.

[5] Jaringan Dokumentasi dan Informasi Kementerian BPK. (2020) Undang-Undang Nomor 11 Tahun 2020 tentang Cipta Kerja Sektor Transfortasi. [Online]. https://peraturan.bpk.go.id/Home/Details/149750/uu-no-11-tahun-2020

[6] Alfan Syukri Hasibuan, "Analisis Kualitas Pelayanan di Bengkel Mobil Mondan Kasikan Kec. Tapung Hulu Kab. Kampar Provinsi Riau," Jurnal Fakultas Ekonomi dan Sosial, vol. 8, no. 5, p. 55, 2019.

[7] Georgy S.V. Watung and Vicky H. Makarau, "Atsitektur High Tech Pada Bangunan Otomotif," Media Matrasain, vol. 10, No.2, pp. 11-18, 2013.

[8] Meynar Telew and Steven Lintong, "Arsitektur High Tech," Media Matrasain, vol. 8, No. 2, pp. 94-106, 2011.

[9] Muhammad Nur Hasan, Perancnagan Pusat Pengolahan Susu Sapi di Pujon, Kabupaten Malang. Malang: Universitas Islam Negeri Maulana Malik Ibrahim, 2014.

[10] Dhona Chandra Prandana, Karya Widyawanti, and Nia Suryani, "Perancangan Aquatic Center dengan pendekatan arsitektur kontemporer di Sumedang Sebagai Pemersatu Transisi Ruang Seperti Yang Terjadi Di Kota-Kota Besar," Seminar Nasional"Komunitas dan Kota Keberlanjutan", p. 3, 2019.

[11] Fanny Salwa Fairuzy, Enny Supriati Sardiyarso, and Sry Handjajanti, "Penerapan Arsitektur High-Tech Pada Fasad Rencana Stasiun MRT Lebak Bulus," Prosiding Seminar Intelektual Muda, vol. 1. No.1, pp. 117-124, 2019.

[12] I Gusti Ayu Eka Suwintari, I Made Trisna Semara, and I Nyoman Sudiarta, "Model Parkir Berbasis Automatic Pada Kawasan Wisata (Studi Kasus DiDestinasi Wisata Kuta, Bali)," Jurnal Ilmiah Hospitality Management, vol. 10, pp. 53-63, 2019.

[13] I Gusti Raka Purbanto, "Karakteristik Parkir Pinggir Jalan (On Street Parking) dan Pengaruhnya Terhadap Kinerja Ruas Jalan," Jurnal Ilmiah Teknik Sipil, vol. 16/No.2, pp. 167-176, 2012.

[14] Almadora Anwar Sani, Ali Medi, Irawan Malik, and Muchtar Ginting, "Desain Tempat 
Parkir Sepeda Motor Bertingkat Dengan Sistem Otomatis," Jurnal Austenit, vol. 10/No.1, pp. 1-9, 2018.

[15] Kanoasa Akbar, Agung Murti Nugroho, and Ali Soekirno, "Penerapan Kinetic Facade dengan Pendekatan Biomimicry pada Pusat Robotika Surabaya," Jurnal Mahasiswa Arsitektur UB, vol. 2/No. 2, 2014.

[16] Gendis Dwi Rahma Widasari, "Penerapan Desain Fasad Yang Menyesuaikan Iklim dan Cuaca Setempat pada Perancangan The Hills Resort Lembang," Jurnal Arsitektur Itenas, vol. 4/No.2, pp. 1-13, 2019.

[17] Dinas Lingkungan Hidup Pemerintah Kota Surabaya. (2019, Mei) Materi Sosialisasi Perencanaan Pembangunan Instalasi Pengolahan Air Limbah (IPAL) untuk Kegiatan Bengkel.

[Online]. http://h.surabaya.go.id/fileupload/BUKU\%20PETUNJUK\%20TEKNIS\%20IPAL\%20BE NGKEL\%2027agustus2019.pdf 